Editorial

\title{
Introduction to the Special Issue "A Systemic Perspective on Urban Food Supply: Assessing Different Types of Urban Agriculture"
}

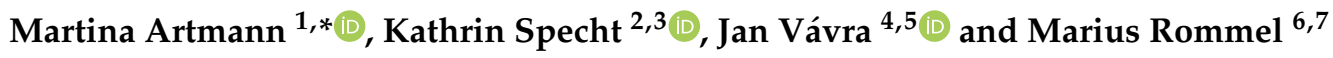 \\ 1 Leibniz Institute of Ecological Urban and Regional Development, Weberplatz 1, 01217 Dresden, Germany \\ 2 ILS-Research Institute for Regional and Urban Development, Brüderweg 22-24, 44135 Dortmund, Germany; \\ kathrin.specht@ils-forschung.de or spechtka@hu-berlin.de \\ 3 Department of Agricultural Economics, Humboldt-Universität zu Berlin, Unter den Linden 6, \\ 10099 Berlin, Germany \\ 4 Faculty of Economics, University of South Bohemia in České Budějovice, Studentská 13, \\ 37005 České Budějovice, Czech Republic; jvavra@ef.jcu.cz or jan.vavra@ujep.cz \\ 5 Faculty of Social and Economic Studies, Jan Evangelista Purkyně University in Ústí nad Labem, Moskevská \\ 54, 40096 Ústí nad Labem, Czech Republic \\ 6 Faculty of Economics, Research Center Pluralist Economics, University Siegen, Adolf-Reichwein-Straße 2, \\ 57076 Siegen, Germany; marius.rommel@uni-siegen.de \\ 7 The Institute for Future-Fit Economies, ZOE, Thomas-Mann-Straße 36, 53111 Bonn, Germany \\ * Correspondence: m.artmann@ioer.de
}

Citation: Artmann, M.; Specht, K.; Vávra, J.; Rommel, M. Introduction to the Special Issue "A Systemic Perspective on Urban Food Supply: Assessing Different Types of Urban Agriculture". Sustainability 2021, 13, 3798. https://doi.org/10.3390/ su13073798

Academic Editor: Marc A. Rosen

Received: 19 March 2021

Accepted: 23 March 2021

Published: 30 March 2021

Publisher's Note: MDPI stays neutral with regard to jurisdictional claims in published maps and institutional affiliations.

Copyright: (c) 2021 by the authors. Licensee MDPI, Basel, Switzerland. This article is an open access article distributed under the terms and conditions of the Creative Commons Attribution (CC BY) license (https:// creativecommons.org/licenses/by/ $4.0 /)$.

\begin{abstract}
The production of food within cities through urban agriculture can be considered as a nature-based solution and is argued to be an important response to the current COVID-19 pandemic as well as to climate change and other urban challenges. However, current research on urban agriculture is still fragmented, calling for a systematic and integrative assessment of different forms of urban agriculture and the drivers and constraints for their effective realization. In this context, the Special Issue presents conceptual and empirical research articles from around the world on the impact and implementation potential of various types of urban agriculture. The studies of this Special Issue cover a broad range of impact and implementation dimensions, asssessment methods and geographical backgrounds that can support future studies to develop a systemic perspective on urban food production.
\end{abstract}

Keywords: urban food production; urban gardening; urban farming; assessment; edible cities; ecosystem services

\section{Introduction}

Today's society is facing a range of challenges connected with urbanization, such as climate change, social segregation, or resource depletion. Due to the complexity of societal challenges and urban systems, there is an increasing need to foster systemic solutions evolving multidimensional benefits for society, nature, and the economy [1]. The production of food within cities through urban agriculture (UA) can be considered a nature-based solution positively contributing to environmental, social, and economic challenges, such as climate change mitigation and adaptation, social cohesion and economic development by providing green jobs, for instance [2], and securing regional resilience [3]. The value of urban food production becomes increasingly visible in times of crisis, in particular, and is argued to be a crucial response to the current COVID-19 pandemic, fostering food security and access to green spaces in cities [4,5].

Cities can be composed of a mosaic of different forms of UA. UA as a dynamic multifunctional phenomenon itself varies significantly in terms of forms and functions. Krikser et al. [6] developed a typology that helps to display the diversity of UA types 
along three beneficial dimensions marking the degree of market-orientation (self-supply, sociocultural, commercial). If self-supply is the driver of UA, individuals produce and consume on a microlevel, meaning that the goods remain in the household or are used by the individual producer. In sociocultural $U A$, initiatives are driven by the need for social inclusion, cultural exchange, or educational factors. Community gardens or intercultural gardens are typical examples of this type. The commercial UA type is based on for-profit interests and includes, for example, commercial urban farms. Even though many gardens and farms follow one major goal, Krikser et al. [6] also point out that these are "ideal types", and the typology is not as clear-cut. Transition processes happening between types and UA types with mixed goals are very common.

Additionally, UA can be technologically oriented (e.g., aquaponics combining hydroand aquaculture [7]) or take a natural agriculture approach (e.g., permaculture fostering natural cycles $[2,8]$ ). Based on controlled urban food production, technology-oriented types of UA can maximize urban food supply and reduce at the same time negative climate impacts through reduced food miles [9]. However, these benefits can be jeopardized by high energy and water demands $[10,11]$. In contrast to technology-oriented food production, it is argued in the context of nature-based solutions to promote natural system agriculture [12] fostering multifunctional ecosystems, landscapes, and ecosystem services by considering, for instance, perennial polycultures, biological pest control, and soil-based cultivation methods $[13,14]$. A range of cities worldwide are currently developing innovative naturebased urban food production projects as a countermovement to input-intensive, hightech industrial agriculture. For instance, the city of Albi (France) aims at increasing its food self-sufficiency based on permaculture [15], or in Milwaukee (US), diverse urban community-based food activism is promoting food justice, neighborhood revitalization, and public health through community gardens, parks, and fruit orchards [16]. However, such experimental urban food production alternatives are at risk of becoming niche players which fail to develop economic relevance due to, for instance, a lack of efficiency in food supply [17]. Often, the key issue seems to be the dilemma between being small enough as an initiative to allow for social relationships and cohesion to emerge, but big enough to operate efficiently in order to allow for either a sufficient amount of self-supply or affordable prices [18].

While many of the above-mentioned types of UA are "modern" and intentional methods for achieving sustainable food systems while enabling social cohesion, traditional gardening has been common in urban areas of many countries [19] for many years. Be it home [20] or allotment gardening [21,22], it often provides positive environmental benefits, since food is produced in a nature-based style [20], and positive social aspects are manifested [23]. Nevertheless, these types of urban gardening have been marginalized in the research [24], especially when compared to popular topics such as community gardening [25]. In this context, it seems necessary to derive the multidimensional effects of UA types in relation to their respective degree of market orientation. It is indeed necessary to assess which multifunctional goals are at the core of a certain initiative, whereas commercial actors score with mostly efficient production facilities, self-supply, and sociocultural initiatives contribute to community building and mostly have more freedom to produce ecologically to a higher degree due to fewer market constraints [18].

Current research on UA is still fragmented, calling for a systematic and integrative assessment of different forms of UA to better understand diverse benefits and risks of the different types of nature-based and technology-oriented UA and their drivers and constraints for its effective realization [2]. In this context, we, as the guest editors of this Special Issue on "A Systemic Perspective on Urban Food Supply: Assessing Different Types of Urban Agriculture", have solicited conceptual and empirical international research articles on the impact and implementation potential for various types of UA. 


\section{The Special Issue and Its Core Themes}

In addition to an open call for papers, this Special Issue is the result of various sessions on UA which took place in the course of the Ecosystem Services Partnership (ESP) Europe conference 2018 in San Sebastian (Spain) focusing on "Urban agriculture and ecosystem services" [26], the IALE World Congress 2019 in Milan (Italy) discussing contributions around the topic "From urban agriculture to edible cities—challenges and chances for approaching sustainable urban socio-ecological systems" [27], and the Dresden Nexus Conference 2020 (Germany) dealing with "Urban agriculture: a systemic approach for integrated natural resource management and socio-economic benefits" [28]. Authors of the most promising contributions in these sessions were invited to submit a paper to this Special Issue. In total, the Special Issue comprises 15 articles including one conceptual paper and 14 case studies from different countries: Australia, Benin, China, Czechia, France, Germany, Italy, Mexico, New Zealand, Sweden, the Netherlands, and the UK. The cases presented in this Special Issue reflect the diversity of UA types following the typology of Krikser et al. [6]. It contains contributions on sociocultural [25,29-32], commercial [33-35] and self-supply [36,37] UA types, along with studies focusing on either varying or mixed UA types [38-41]. Comparing the scope of the studies in terms of focusing on technology- or nature-based UA, the majority of the papers deal with nature-based forms of UA $[25,29-31,36,39,40,42]$, while only three papers investigate technology-oriented types of UA [33,35,37] (see Figure 1). All in all, the case studies cover towns and cities all over the world and address a wide range of various types of UA, its impact and implementation dimensions, research objectives, and methodologies reflecting the interdisciplinarity and international research of UA.

In the next sections, we provide a synthesis of the papers structured around the major aims of the Special Issue (see Table 1).

\subsection{Implementing Urban Agriculture}

In total, seven papers in this Special Issue deal with drivers and constraints for implementing various types of UA. Hereby, the focus of three papers is on the social dimension [30,31,34]; two papers take into account a multidimensional [25,36], one a political [42], and a conceptual paper a systemic perspective [38].

From the papers analyzing social framework conditions for implementing UA, two focus on community gardens [30,31]. The study by Ding et al. [31] on community gardens in China found that spatial factors such as accessibility, size, and visual openness have an impact on the social capital. These factors should be taken into account by urban planners and designers when implementing and retrofitting community gardens. The importance of such spatial factors is in contrast to the study on driving forces of residents engaging in Czech community gardens [30]. Dubová et al. found that the location of the gardens within the urban pattern does not explain why people engage in community gardens. The findings suggest that residents of Czech cities are motivated to engage in community gardens for recreational purposes, social exchange, and the joy of urban gardening. However, motives for joining community gardens can differ depending on previous gardening experiences, its lengths, and sociodemographic factors [30]. In a similar vein, the importance of the family tradition of commercial farming in Australia for pursuing sustainable livelihoods was confirmed by Diehl [34]. The author highlights that personal relationships between producers and consumers as well as among the family of the farmer and the farmers themselves are crucial for establishing a resilient urban food system. Although this study focuses on commercial farming, Diehl assumes that these drivers and constraints may also hold true for the implementation of other UA types. 
Table 1. Systematization of papers published in this Special Issue. (Note: UA: Urban agriculture).

\begin{tabular}{|c|c|c|c|c|c|c|}
\hline No. & Authors & UA Type & Case Study Scope & $\begin{array}{c}\text { Study } \\
\text { Dimension }\end{array}$ & $\begin{array}{l}\text { Assessment } \\
\text { Approach }\end{array}$ & Research Subject \\
\hline 1 & $\begin{array}{l}\text { Núñez- } \\
\text { Ríos et al. } \\
\text { [38] }\end{array}$ & Undefined & $\begin{array}{l}\text { N.A. (conceptual } \\
\text { study) }\end{array}$ & $\begin{array}{l}\text { UA } \\
\text { implementation- } \\
\text { systemic } \\
\text { dimension }\end{array}$ & N.A. & $\begin{array}{c}\text { Multilevel and } \\
\text { multistakeholder } \\
\text { relationships of sustainable } \\
\text { urban self-sufficient food } \\
\text { production }\end{array}$ \\
\hline 2 & $\begin{array}{l}\text { Clerino and } \\
\text { Fargue- } \\
\text { Lelièvre } \\
\text { [33] }\end{array}$ & $\begin{array}{l}\text { Professional intra-urban } \\
\text { farms including multi- } \\
\text { functional microfarms, } \\
\text { greenhouses and indoor } \\
\text { systems }\end{array}$ & $\begin{array}{l}\text { Non-comparative } \\
\text { case study }\end{array}$ & $\begin{array}{l}\text { UA impacts- } \\
\text { multidimensional }\end{array}$ & $\begin{array}{l}\text { Focus groups, online } \\
\text { survey, interviews }\end{array}$ & $\begin{array}{l}\text { Sustainability objectives and } \\
\text { criteria applicable to } \\
\text { professional intra-urban } \\
\text { farms }\end{array}$ \\
\hline 3 & $\begin{array}{l}\text { Houessou } \\
\text { et al. [36] }\end{array}$ & Allotment gardens & $\begin{array}{l}\text { Non-comparative } \\
\text { case study }\end{array}$ & $\begin{array}{l}\text { UA } \\
\text { Implementation- } \\
\text { multidimensional }\end{array}$ & $\begin{array}{l}\text { Literature review, } \\
\text { survey, interviews }\end{array}$ & $\begin{array}{l}\text { Constraints for the } \\
\text { expansion of urban } \\
\text { allotment gardens in Benin }\end{array}$ \\
\hline 4 & $\begin{array}{l}\text { Schoen } \\
\text { et al. [29] }\end{array}$ & Community gardens & $\begin{array}{l}\text { Non-comparative } \\
\text { case study }\end{array}$ & $\begin{array}{l}\text { UA impacts- } \\
\text { socioeconomic } \\
\text { dimensions }\end{array}$ & $\begin{array}{c}\text { Combination of } \\
\text { interviews, } \\
\text { questionnaires and } \\
\text { economic analyses }\end{array}$ & $\begin{array}{l}\text { Return of investment by } \\
\text { urban community gardens }\end{array}$ \\
\hline 5 & $\begin{array}{c}\text { van de } \\
\text { Vlasakker } \\
\text { and Veen } \\
\text { [37] }\end{array}$ & $\begin{array}{l}\text { High-tech indoor } \\
\text { gardens }\end{array}$ & $\begin{array}{l}\text { Non-comparative } \\
\text { case study }\end{array}$ & $\begin{array}{l}\mathrm{UA} \\
\text { impacts-social } \\
\text { dimension }\end{array}$ & $\begin{array}{l}\text { Site visits, interviews, } \\
\text { surveys }\end{array}$ & $\begin{array}{l}\text { Affects by urban high-tech } \\
\text { indoor gardening practices } \\
\text { on cooking and eating } \\
\text { practices in nursing homes }\end{array}$ \\
\hline 6 & $\begin{array}{l}\text { Xie et al. } \\
\text { [39] }\end{array}$ & Urban agriculture parks & $\begin{array}{l}\text { Comparison } \\
\text { between various } \\
\text { sites of the same } \\
\text { UA-type }\end{array}$ & $\begin{array}{l}\text { UA } \\
\text { impacts-social } \\
\text { dimension }\end{array}$ & $\begin{array}{l}\text { Analysis of landscape } \\
\text { patterns (spatial } \\
\text { analysis), pre-ference } \\
\text { analysis (survey), } \\
\text { interviews }\end{array}$ & $\begin{array}{l}\text { Landscape services } \\
\text { provided by urban } \\
\text { agriculture parks }\end{array}$ \\
\hline 7 & $\begin{array}{l}\text { Muñoz- } \\
\text { Rodríguez } \\
\text { et al. [42] }\end{array}$ & Home gardens & $\begin{array}{l}\text { Comparison } \\
\text { between various } \\
\text { sites of the same } \\
\text { UA-type }\end{array}$ & $\begin{array}{c}\text { UA } \\
\text { Implementation- } \\
\text { political } \\
\text { dimension }\end{array}$ & Site visits, survey & $\begin{array}{l}\text { Effectiveness of public } \\
\text { policy strengthening urban } \\
\text { food self-production by } \\
\text { home gardens }\end{array}$ \\
\hline 8 & Diehl [34] & Commercial farms & $\begin{array}{l}\text { Comparison } \\
\text { between various } \\
\text { sites of the same } \\
\text { UA-type }\end{array}$ & $\begin{array}{c}\text { UA } \\
\text { Implementation- } \\
\text { social } \\
\text { dimension }\end{array}$ & $\begin{array}{l}\text { Site visits, } \\
\text { semi-structured } \\
\text { interviews }\end{array}$ & $\begin{array}{l}\text { Access to and use of } \\
\text { tangible and intangible } \\
\text { resources of the urban food } \\
\text { system by commercial } \\
\text { urban farmers }\end{array}$ \\
\hline 9 & $\begin{array}{l}\text { Wesener } \\
\text { et al. [25] }\end{array}$ & Community gardens & $\begin{array}{l}\text { Comparison } \\
\text { between various } \\
\text { countries }\end{array}$ & $\begin{array}{l}\text { UA } \\
\text { Implementation- } \\
\text { multidimensional }\end{array}$ & $\begin{array}{l}\text { Literature review, } \\
\text { interviews }\end{array}$ & $\begin{array}{c}\text { Enablers and barriers for the } \\
\text { development of urban } \\
\text { community gardens }\end{array}$ \\
\hline 10 & $\begin{array}{l}\text { Martin and } \\
\text { Molin [35] }\end{array}$ & $\begin{array}{l}\text { Urban vertical farming } \\
\text { systems }\end{array}$ & $\begin{array}{l}\text { Non-comparative } \\
\text { case study }\end{array}$ & $\begin{array}{l}\text { UA impacts- } \\
\text { environmental } \\
\text { dimension }\end{array}$ & $\begin{array}{l}\text { Life cycle assessment } \\
\text { (LCA) }\end{array}$ & $\begin{array}{l}\text { Environmental impacts of } \\
\text { vertical hydroponic farming } \\
\text { in urban environments }\end{array}$ \\
\hline 11 & $\begin{array}{l}\text { Šlachta } \\
\text { et al. [40] }\end{array}$ & $\begin{array}{l}\text { Commercial fruit } \\
\text { orchards, suburban } \\
\text { gardens }\end{array}$ & $\begin{array}{l}\text { Comparison } \\
\text { between various } \\
\text { UA-types and their } \\
\text { spatial location }\end{array}$ & $\begin{array}{l}\text { UA impacts- } \\
\text { environmental } \\
\text { dimension }\end{array}$ & $\begin{array}{c}\text { Biomonitoring } \\
\text { (palynological } \\
\text { analyses, pesticide } \\
\text { analysis) }\end{array}$ & $\begin{array}{l}\text { Role of domestic gardens } \\
\text { mitigating the risk of } \\
\text { exposure for pollinators to } \\
\text { pesticides based on an } \\
\text { urban-rural case study }\end{array}$ \\
\hline 12 & $\begin{array}{l}\text { Dubová } \\
\text { et al. [30] }\end{array}$ & Community gardens & $\begin{array}{c}\text { Comparison } \\
\text { between various } \\
\text { spatial locations of } \\
\text { the same UA type }\end{array}$ & $\begin{array}{c}\text { UA } \\
\text { Implementation- } \\
\text { social } \\
\text { dimension }\end{array}$ & Surveys & $\begin{array}{l}\text { Drivers for urban residents } \\
\text { participating in community } \\
\text { gardens }\end{array}$ \\
\hline 13 & $\begin{array}{l}\text { Sanyé- } \\
\text { Mengual } \\
\text { et al. [41] }\end{array}$ & $\begin{array}{l}\text { Indoor farming, } \\
\text { high-tech greenhouses, } \\
\text { peri-urban farms, urban } \\
\text { farms, community } \\
\text { rooftop gardens }\end{array}$ & $\begin{array}{c}\text { Comparison } \\
\text { between various } \\
\text { UA types and UA } \\
\text { stakeholders }\end{array}$ & $\begin{array}{l}\text { UA Impact- } \\
\text { multidimensional }\end{array}$ & Surveys & $\begin{array}{c}\text { Perceptions of project } \\
\text { leaders, stakeholders and } \\
\text { the general public on } \\
\text { ecosystem services provided } \\
\text { by various types of urban } \\
\text { agriculture }\end{array}$ \\
\hline 14 & $\begin{array}{l}\text { Ding et al. } \\
{[31]}\end{array}$ & Community gardens & $\begin{array}{l}\text { Non-comparative } \\
\text { case study }\end{array}$ & $\begin{array}{c}\text { UA } \\
\text { Implementation- } \\
\text { social } \\
\text { dimension }\end{array}$ & $\begin{array}{l}\text { Questionnaire; factor } \\
\text { analysis }\end{array}$ & $\begin{array}{l}\text { The role of design and social } \\
\text { factors affecting the } \\
\text { formation of social capital in } \\
\text { community gardens }\end{array}$ \\
\hline 15 & $\begin{array}{l}\text { Giacchè } \\
\text { et al. [32] }\end{array}$ & Microfarms & $\begin{array}{l}\text { Comparison } \\
\text { between various } \\
\text { sites of the same } \\
\text { UA- type and } \\
\text { various UA } \\
\text { stakeholders }\end{array}$ & $\begin{array}{l}\text { UA } \\
\text { dimpacts-social } \\
\text { dimension }\end{array}$ & $\begin{array}{c}\text { On-site-visits; } \\
\text { semi-structured } \\
\text { interviews; online } \\
\text { questionnaire, } \\
\text { photographic } \\
\text { questionnaire }\end{array}$ & $\begin{array}{l}\text { Evaluation of exogenous } \\
\text { and endogenous cultural } \\
\text { ecosystem services provided } \\
\text { by urban micro-farms }\end{array}$ \\
\hline
\end{tabular}




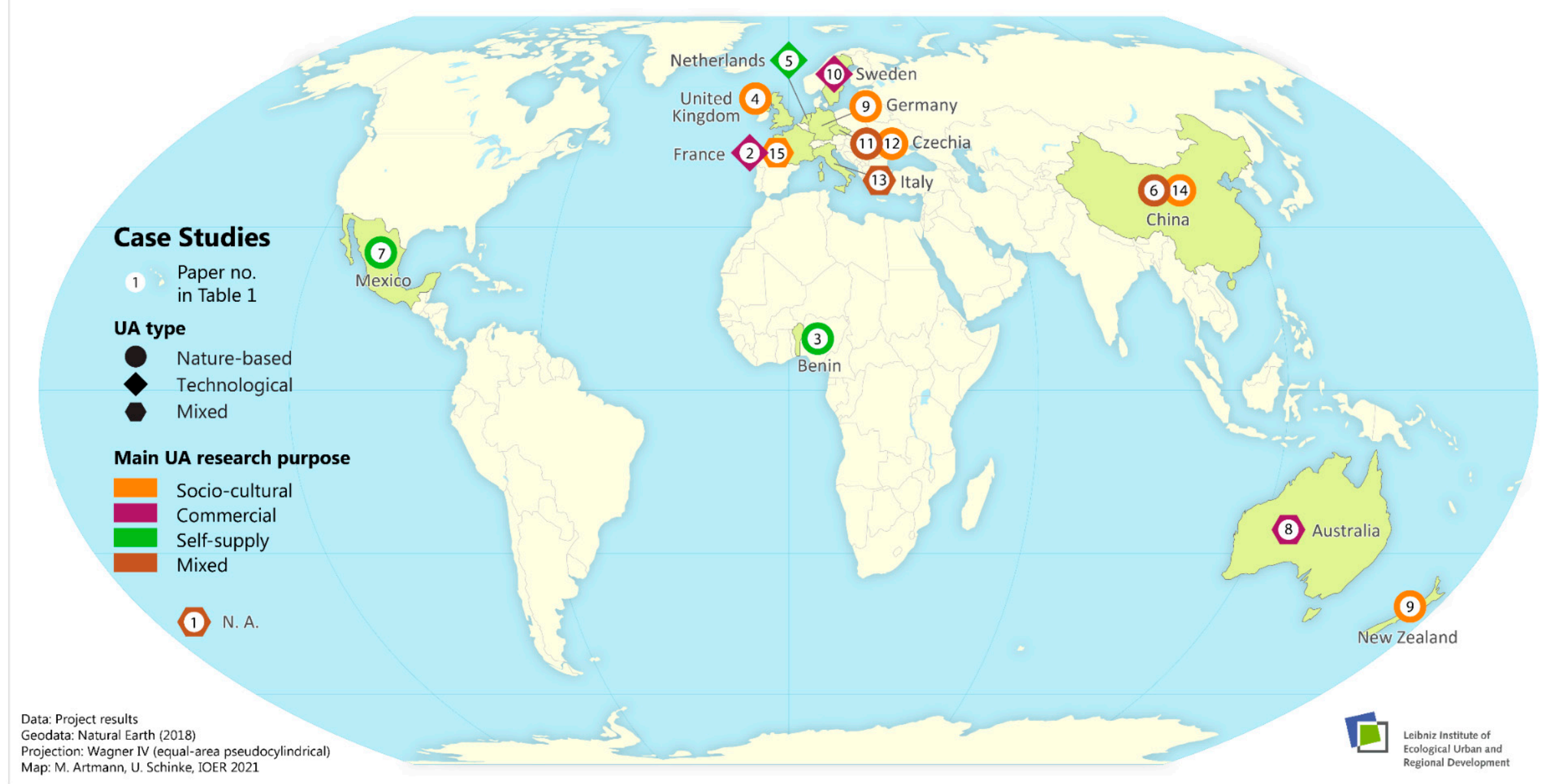

Figure 1. Geographical distribution of studies presented in the Special Issue (Note: Paper no. 1 [38] refers to a conceptual paper and has no geographical context). 
A multidimensional UA implementation study by Wesener et al. [25] found that connection to and interest shown by local communities and social networks are crucial enabling factors for community gardens including, for instance, networks for mutual exchange and support among gardeners and their communities. In this regard, the authors highlight the demand to analyze drivers and constraints for implementing community gardens through the lens of various stakeholders and by taking into account different national planning cultures. In fact, this study was the only one in this Special Issue implementing a transnational case study while focusing on Germany and New Zealand [25]. The significance of a lack of government support constraining the expansion and maintenance of UA was confirmed by Houessou et al. [36] and Muñoz-Rodríguez et al. [42]. In the case study of Houessou et al. [36] in Benin, the authors highlight that in addition to an insecure access to urban land, restricted marked access and inequality issues, insufficient government support is hindering the expansion of UA in Benin [36]. The authors suggest that the assessment of the benefits provided by UA (such as conducted by $[29,32,33,35,37,39,40]$, see Section 2.2) can strengthen the political will to consider UA as an important part of an ecologically, economically, and socially sound urban development.

By analyzing the effectiveness of different government programs and their factors supporting or constraining the persistence or abandonment of home gardens for strengthening food security in Mexico, the study by Muñoz-Rodríguez et al. [42] shows that only a small percentage of rural and urban low-income families profit from producing their own vegetables through home gardens. Interestingly, in their study, urban home gardens had a higher probability of operational persistence when compared to rural home gardens. The authors therefore highlight the need for multidimensional and systemic approaches which take into account the various types of populations, their habits, culture, needs, and available resources to formulate effective policies [42]. In fact, by using a Social Network Analysis and a Viable System Model, the conceptual paper by Núñez-Ríos et al. [38] identified key factors related to contextual, operational, and management components for understanding sustainable urban food production systems. The authors highlight that their framework can be used for future research on UA and its various contexts.

\subsection{Impacts of Urban Agriculture}

Eight papers in this Special Issue focus on impacts of UA, its assessment, and related recommendations for sustainable urban development. Similar to the studies in this Special Issue dealing with the implementation of UA, the focus of the papers on UA impacts is on the social dimension $[32,37,39]$ and related multidimensional impacts $[33,41]$. Two papers deal with environmental impacts [35,40], and one takes a socioeconomic perspective [29].

When analyzing UA impacts socially [32,39] or multidimensionally [41], some studies applied the ecosystem services approach. In this regard, a Chinese case study by Xie et al. [39] assessing landscape services provided by urban agricultural parks found that service supply and demand both lack scenery services, which should be considered when planning UA. Interestingly, while Dubová et al. [30] suggested that drivers for engaging in community gardens differ among various population groups (see Section 2.1), also perceived impacts provided by UA differ among various UA actor groups [33,39,41].

In the Chinese case study on UA parks, landscape service demand differs between population groups depending on the income, age, and education of the residential UA users [39]. In an Italian case study on various types of UA, Sanyé-Mengual et al. found that the public and stakeholders both value in particular sociocultural ecosystem services provided by UA, whereas provisioning ecosystem services are more highly valued by the general public. Stakeholders with a relation to UA networks appreciated sociocultural ecosystem services on average more [41]. A case study on professional intraurban farms in France [33] found that, in particular, social criteria were evaluated together with environmental criteria as more important than economic ones. The results of this paper by Clerino and Fargue-Lelièvre suggest that decision-makers assessed societal external sustainability issues as crucial criteria of professional intraurban farms. In contrast, urban farmers rate 
internal sustainability, including its contribution to quality of life and maintenance of independence, as particularly important. To better understand the various impacts of UA, a French case study by Giacchè et al. [32] on cultural ecosystem services provided by urban microfarms emphasized that further differentiation of actors benefiting from UA is needed. Thus, the authors tend to differ in their opinions of endogenously induced effects for UA users and exogenously induced effects for non-users such as urban residents or passersby in areas where UA is located. As another example for a social endogenously induced effect for UA users, a Dutch study on high-tech indoor gardens located in care facilities for elderly found that indoor gardens resulted in a transformation of the seniors' eating practices, and the staff were happy to serve healthier meals to the elderly residents [37]. Furthermore, van de Vlasakker and Veen highlighted that the indoor gardens were valued by the seniors in terms of the taste and appearance of the fresh vegetables served and the possibility to observe the growth of the edible plants.

Social UA benefits demonstrated in the papers presented above can also be linked to economic UA impacts, as was done in a study from the UK by Schoen et al. [29]. Based on a cost-benefit analysis, the authors assessed the social return of investment by community gardens. Their results suggest that the food grown in a community garden in London fosters a social return of GBP 3 for every GBP 1 invested. The authors highlight that their findings can be used to increase the political will to consider UA of high value in urban planning, an issue which is crucial for an effective UA implementation, as was shown in studies presented in Section 2.1.

In terms of environmental UA impacts, the papers presented in this Special Issue focus on the environmental impacts of vertical hydroponic farming in urban environments in Sweden [35] and the role of domestic gardens mitigating the pollinators' risk of exposure to pesticides in an urban-rural case study in the Czechia [40]. Based on a life cycle perspective, the Swedish case study by Martin and Molin found that the most crucial factors for the vertical hydroponic system are the growing medium, pots, electricity demand, transportation of raw materials, and product deliveries [35]. By comparing potential options to reduce harmful environmental impacts, the authors highlight that, for instance, replacements of plastic with paper pots and conventional gardening soil with coir can strengthen positive impacts of this UA type. However, more effort is needed to decrease the electricity demand in the vertical growing system and to develop more reciprocal exchanges of urban waste deliveries and its byproducts. In this regard, an urban UA context can profit from shorter supply chains, thereby improving transportation losses and securing food quality. The study by Šlachta et al. [40] stressed the beneficial role of urban domestic gardens for supporting biodiversity. By focusing on an experimental solitary bee, the authors found that domestic gardens provide pollinators forage that was less contaminated by pesticides compared to close rural areas with commercial orchards. Thus, these findings confirm the importance of domestic gardens to support biodiversity in urban landscapes.

\subsection{Methodological and Conceptual Implications}

This Special Issue presents a wide range of possible tools and methods to assess UA. Looking at the portfolio of applied methods throughout this Special Issue, it becomes very clear that there is not only one fitting approach to assess sustainability impacts of UA and its implementation, but a whole set of suitable methods exists, which target the different sustainability dimensions. Among others, the methods range from assessment tools in the economic dimension (such as cost-benefit analysis [29]) over assessments of the social dimension (e.g., through interviews on social capital [31] or surveys among urban residents participating in community gardens [30]) to environmental analysis (such as life-cycle assessments) [35] or biomonitoring to measure impacts on biodiversity [40] depending on the targeted sustainability impacts.

Looking at this broad picture of potential measurements of UA impacts and implementation, there is further no clear preference for either quantitative or qualitative methods 
(see Figure 2). While two studies relied on pure qualitative analysis $[25,34]$ and five on quantitative analysis $[30,31,35,40,41]$, the majority of eight studies used mixed-methods approaches and combined qualitative methods (e.g., focus group discussions, stakeholder workshops, on-site visits, or expert interviews) with quantitative methods (e.g., online questionnaires or on-site surveys) $[29,32,33,36-39,42]$. Given the multidimensional impacts of UA and its general multifunctionality [2,43], a mixed-methods approach often seems to be an advisable choice to tackle the different dimensions. Using various methods usually allows the researchers to get insight into the problem (e.g., understanding of respondents or important details), while still having broad coverage of the issue (receiving answers from representative samples of respondents, data for economic calculations, etc.).

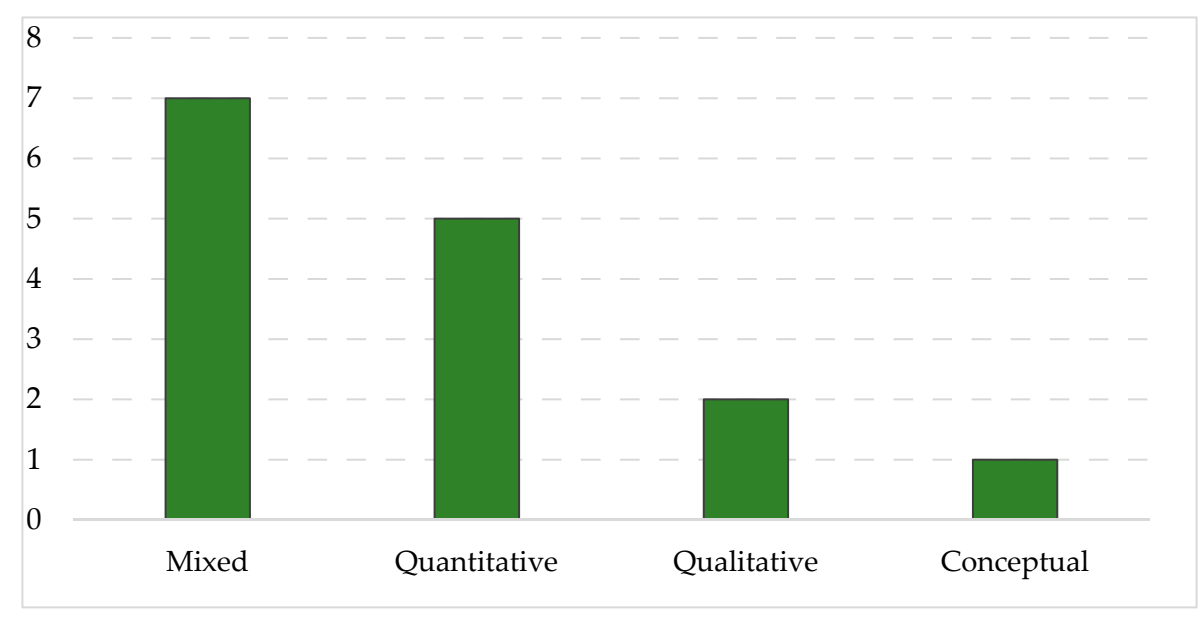

Figure 2. Number of papers per methodological approach.

In terms of the case study scope analyses of whether the papers did any comparisons, 6 out of 15 studies rely on non-comparative case studies [29,31,33,35-37]. Four studies compare various sites of the same UA-type [32,34,39,42]. Only two studies compare various types of UA [40,41], while Šlachta et al. [40] and Dubová et al. [30] also take into account any differences between the spatial location of UA. Only Wesener et al. [25] compare UA between various countries (Germany and New Zealand). One study does not apply any case study approach and is a conceptual study [38]. The use of non-comparative case studies represents a general trend in UA studies. One common drawback of noncomparative case studies is the limitation in the generalization of the results. They can mostly be understood as seminal cases. If it comes to the transferability of studies, it is often assumed that similar results would be found in other case studies, in similar spatial contexts with similar characteristics. Nonetheless, results may differ geographically and culturally, which is why we see it as very promising for future research to repeat successful studies and apply them in other contexts in order to validate the results and make the findings more robust. Applying proven frameworks to new case studies would allow one to arrive at a higher overall number of comparative studies. Furthermore, future studies could also attempt to incorporate additional comparative case studies into the study design from the beginning.

\section{Concluding Remarks}

The scope of this Special Issue was to identify advantages and disadvantages of various UA types in terms of their implementation and impacts. This issue proves that such a differentiated view is meaningful, taking into account the broad range of presented UA types, their impacts, as well as the drivers for and constraints against implementation (see Section 2, Figure 1 and Table 1). However, only a few studies in this Special Issue conducted a systemic comparison between various UA types [40,41] or countries [25] calling for further systematic comparative studies between various types of UA, their geographical backgrounds, and actor groups. 
In terms of comparative studies between various UA types, authors call for further research on the impact side by focusing on ecosystem service supply-demand relationships [39] and the perceived benefits of different forms of UA [32,41] as well as any differences between environmental impacts between more technical-oriented and naturebased UA [35]. Additionally, a deeper understanding of perceptional differences of barriers among various actor groups for implementing UA is needed $[25,30]$. Such comparative studies may benefit from large-scale research projects implementing case studies from various geographical backgrounds $[25,36,41]$ and taking into account a sufficient number of different UA types and their relevant actors [29,31,37].

In this regard, the value of food production in an urban context can be analyzed in a more multidimensional way. Although the studies of this Special Issue cover a broad range of dimensions, many of the studies focus on the social dimension of implementation and impacts. This might be due to the fact that UA is in particular valued for its social benefits, such as those found in the few multidimensional assessments in this Special Issue $[33,41]$ as well as in other studies [44,45]. However, more research on the multidimensional impacts of UA can make the value of UA visible, which is often at risk due to a lack of access to land, finances, and political will, as reflected by various authors in this Special Issue $[25,29,30]$. In this manner and especially with the experience of the COVID-19 crisis, it seems highly necessary to further investigate the specific contributions that UA can address in terms of internalizing external effects, building up local and resilient food systems, and contributing to democratizing economic activity. Further, in order to secure acceptance of UA, potential UA threats and risks such as contamination of soils or high resource input also need to be considered in more depth [2], which did not play a crucial role in this issue.

To sum up, this Special Issue presented a wide range of UA types in the form of international case studies from around the world, which affords this compilation of articles a particular value. Although a final systemic comparison between various UA types is not possible due to the manifold impact and implementation dimensions analyzed and assessed, this feature confirms that research on UA is of great importance for sustainable urban development. For instance, in an urban context, circular approaches [35], less polluted domestic urban gardens [40], and the use of abandoned land [42] show the great potential of UA to strengthen sustainable urban development. Nevertheless, more research is needed using systemic concepts [38] and developing multidimensional criteria and indicators [33] in order to systemically identify effective ways of upscaling UA implementation and its co-benefits under consideration of its specific cultural and spatial context. This will require a trans- and interdisciplinary approach that fosters the multifunctional benefits in and for the city.

Author Contributions: Conceptualization, investigation and writing-original draft preparation, M.A.; investigation and writing Section 2.3, K.S. and J.V.; writing-review and editing, K.S., J.V. and M.R. All authors have read and agreed to the published version of the manuscript.

Funding: Martina Artmann acknowledges funding support of the Deutsche Forschungsgemeinschaft (DFG, German Research Foundation) (grant number: AR 1121/1-2). Kathrin Specht acknowledges funding from the FEW-meter project (BMBF; Germany, grant number: 01LF1801A). Jan Vávra acknowledges funding support of Czech Science Foundation (grant number: 19-10694S).

Institutional Review Board Statement: Not applicable.

Informed Consent Statement: Not applicable.

Data Availability Statement: Not applicable.

Acknowledgments: The guest editors want to express their sincere gratitude to all authors and reviewers who have contributed their time and effort to make this Special Issue possible.

Conflicts of Interest: The authors declare no conflict of interest. 


\section{References}

1. Raymond, C.M.; Frantzeskaki, N.; Kabisch, N.; Berry, P.; Breil, M.; Nita, M.R.; Geneletti, D.; Calfapietra, C. A Framework for Assessing and Implementing the Co-Benefits of Nature-Based Solutions in Urban Areas. Environ. Sci. Policy 2017, 77, 15-24. [CrossRef]

2. Artmann, M.; Sartison, K. The Role of Urban Agriculture as a Nature-Based Solution: A Review for Developing a Systemic Assessment Framework. Sustainability 2018, 10, 1937. [CrossRef]

3. Lamine, C. Sustainability and Resilience in Agrifood Systems: Reconnecting Agriculture, Food and the Environment: Sustainability and Resilience in Agrifood Systems. Sociol. Rural. 2015, 55, 41-61. [CrossRef]

4. Altieri, M.A.; Nicholls, C.I. Agroecology and the Reconstruction of a Post-COVID-19 Agriculture. J. Peasant Stud. 2020, 47, 881-898. [CrossRef]

5. Vittuari, M.; Bazzocchi, G.; Blasioli, S.; Cirone, F.; Maggio, A.; Orsini, F.; Penca, J.; Petruzzelli, M.; Specht, K.; Amghar, S.; et al. Envisioning the Future of European Food Systems: Approaches and Research Priorities after COVID-19. Front. Sustain. Food Syst. 2021. [CrossRef]

6. Krikser, T.; Piorr, A.; Berges, R.; Opitz, I. Urban Agriculture Oriented towards Self-Supply, Social and Commercial Purpose: A Typology. Land 2016, 5, 28. [CrossRef]

7. Specht, K.; Weith, T.; Swoboda, K.; Siebert, R. Socially Acceptable Urban Agriculture Businesses. Agron. Sustain. Dev. 2016, $36,17$. [CrossRef]

8. Permaculture Association Change Your World. Available online: http:/ / www.permaculture.org.uk/ (accessed on 2 February 2021).

9. Despommier, D. Farming up the City: The Rise of Urban Vertical Farms. Trends Biotechnol. 2013, 31, 388-389. [CrossRef]

10. Garcia, X.; Llausàs, A.; Ribas, A.; Saurí, D. Watering the Garden: Preferences for Alternative Sources in Suburban Areas of the Mediterranean Coast. Local Environ. 2015, 20, 548-564. [CrossRef]

11. Goldstein, B.; Hauschild, M.; Fernández, J.; Birkved, M. Testing the Environmental Performance of Urban Agriculture as a Food Supply in Northern Climates. J. Clean. Prod. 2016, 135, 984-994. [CrossRef]

12. Eggermont, H.; Balian, E.; Azevedo, J.M.N.; Beumer, V.; Brodin, T.; Claudet, J.; Fady, B.; Grube, M.; Keune, H.; Lamarque, P.; et al. Nature-Based Solutions: New Influence for Environmental Management and Research in Europe. Gaia-Ecol. Perspect. Sci. Soc. 2015, 24, 243-248. [CrossRef]

13. Cox, T.S.; Picone, C.; Jackson, W. Research Priorities in Natural Systems Agriculture. J. Crop Improv. 2004, 12, 511-531. [CrossRef]

14. Jackson, W. Natural Systems Agriculture: A Truly Radical Alternative. Agric. Ecosyst. Environ. 2002, 88, 111-117. [CrossRef]

15. Fleischmann, S.; Ulrich, A. Ackern Für Die Zukunft. Natürliche Landwirtschaft in Feld Und Garten. Available online: https: //www.zdf.de/gesellschaft/plan-b/plan-b-ackern-fuer-die-zukunft-102.html (accessed on 2 February 2021).

16. Pettygrove, M.; Ghose, R. From "Rust Belt" to "Fresh Coast": Remaking the City through Food Justice and Urban Agriculture. Ann. Am. Assoc. Geogr. 2018, 108, 591-603. [CrossRef]

17. Pfeiffer, A.; Silva, E.; Colquhoun, J. Innovation in Urban Agricultural Practices: Responding to Diverse Production Environments. Renew. Agric. Food Syst. 2015, 30, 79-91. [CrossRef]

18. Paech, N.; Sperling, C.; Rommel, M. Cost effects of local food enterprises: Supply chains, transaction costs and social diffusion. In Food System Transformations: Social Movements, Local Economies, Collaborative Networks; Kropp, C., Antoni-Komar, I., Sage, C., Eds.; Routledge: London, UK; New York, NY, USA, 2021; pp. 119-138.

19. Vávra, J.; Megyesi, B.; Duží, B.; Craig, T.; Klufová, R.; Lapka, M.; Cudlínová, E. Food Self-Provisioning in Europe: An Exploration of Sociodemographic Factors in Five Regions: Food Self-Provisioning in Europe. Rural. Sociol. 2018, 83, 431-461. [CrossRef]

20. Vávra, J.; Daněk, P.; Jehlička, P. What Is the Contribution of Food Self-Provisioning towards Environmental Sustainability? A Case Study of Active Gardeners. J. Clean. Prod. 2018, 185, 1015-1023. [CrossRef]

21. Breuste, J.H.; Artmann, M. Allotment Gardens Contribute to Urban Ecosystem Service: Case Study Salzburg, Austria. J. Urban Plan. Dev. 2015, 141. [CrossRef]

22. Tóth, A.; Duží, B.; Vávra, J.; Supuka, J.; Bihuňová, M.; Halajová, D.; Martinát, S.; Nováková, E. Changing Patterns of Allotment Gardening in the Czech Republic and Slovakia. Nat. Cult. 2018, 13, 161-188. [CrossRef]

23. Jehlička, P.; Daněk, P. Rendering the Actually Existing Sharing Economy Visible: Home-Grown Food and the Pleasure of Sharing: Home-Grown Food and the Pleasure of Sharing. Sociol. Rural. 2017, 57, 274-296. [CrossRef]

24. Jehlička, P.; Grīvinšs, M.; Visser, O.; Balázs, B. Thinking Food like an East European: A Critical Reflection on the Framing of Food Systems. J. Rural Stud. 2020, 76, 286-295. [CrossRef]

25. Wesener, A.; Fox-Kämper, R.; Sondermann, M.; Münderlein, D. Placemaking in Action: Factors That Support or Obstruct the Development of Urban Community Gardens. Sustainability 2020, 12, 657. [CrossRef]

26. Specht, K.; Artmann, M.; Sanyé-Mengual, E. Urban Agriculture and Ecosystem Services. In Proceedings of the Session at the ESP Europe Regional Conference, San Sebastián, Spain, 15-19 October 2018; Available online: https:/ /www.espconference.org/eu201 8/wiki/383431/session-presentations (accessed on 2 February 2021).

27. Artmann, M.; Vávra, J.; Rommel, M. From Urban Agriculture to Edible Cities-Challenges and Chances for Approaching Sustainable Urban Socio-Ecological Systems. In Proceedings of the Session at the IALE World Congress, Milano, Italy, 1-5 July 2019; Available online: https://iale2019.unimib.it/proposed-symposia/symposium_11/ (accessed on 2 February 2021). 
28. Akter, S.; Ioja, C.; Artmann, M. Urban Agriculture: A Systemic Approach for Integrated Natural Resource Management and SocioEconomic Benefits. In Proceedings of the Session at the Dresden Nexus Conference, Dresden, Germany, 3-5 June 2020; Available online: https:/ / 2020.dresden-nexus-conference.org/frontend/index.php?page_id=14807 (accessed on 2 February 2021).

29. Schoen, V.; Caputo, S.; Blythe, C. Valuing Physical and Social Output: A Rapid Assessment of a London Community Garden. Sustainability 2020, 12, 5452. [CrossRef]

30. Dubová, L.; Macháč, J.; Vacková, A. Food Provision, Social Interaction or Relaxation: Which Drivers Are Vital to Being a Member of Community Gardens in Czech Cities? Sustainability 2020, 12, 9588. [CrossRef]

31. Ding, X.; Zhang, Y.; Zheng, J.; Yue, X. Design and Social Factors Affecting the Formation of Social Capital in Chinese Community Garden. Sustainability 2020, 12, 10644. [CrossRef]

32. Giacchè, G.; Consalès, J.-N.; Grard, B.J.-P.; Daniel, A.-C.; Chenu, C. Toward an Evaluation of Cultural Ecosystem Services Delivered by Urban Micro-Farms. Sustainability 2021, 13, 1716. [CrossRef]

33. Clerino, P.; Fargue-Lelièvre, A. Formalizing Objectives and Criteria for Urban Agriculture Sustainability with a Participatory Approach. Sustainability 2020, 12, 7503. [CrossRef]

34. Diehl, J.A. Growing for Sydney: Exploring the Urban Food System through Farmers' Social Networks. Sustainability 2020, $12,3346$. [CrossRef]

35. Martin, M.; Molin, E. Environmental Assessment of an Urban Vertical Hydroponic Farming System in Sweden. Sustainability 2019, 11, 4124. [CrossRef]

36. Houessou, M.D.; van de Louw, M.; Sonneveld, B.G.J.S. What Constraints the Expansion of Urban Agriculture in Benin? Sustainability 2020, 12, 5774. [CrossRef]

37. van de Vlasakker, P.C.H.; Veen, E.J. Effects of High-Tech Urban Agriculture on Cooking and Eating in Dutch Nursing Homes. Sustainability 2020, 12, 5379. [CrossRef]

38. Núñez-Ríos, J.E.; Aguilar-Gallegos, N.; Sánchez-García, J.Y.; Cardoso-Castro, P.P. Systemic Design for Food Self-Sufficiency in Urban Areas. Sustainability 2020, 12, 7558. [CrossRef]

39. Xie, M.; Li, M.; Li, Z.; Xu, M.; Chen, Y.; Wo, R.; Tong, D. Whom Do Urban Agriculture Parks Provide Landscape Services to and How? A Case Study of Beijing, China. Sustainability 2020, 12, 4967. [CrossRef]

40. Šlachta, M.; Erban, T.; Votavová, A.; Bešta, T.; Skalský, M.; Václavíková, M.; Halešová, T.; Edwards-Jonášová, M.; Včeláková, R.; Cudlín, P. Domestic Gardens Mitigate Risk of Exposure of Pollinators to Pesticides-An Urban-Rural Case Study Using a Red Mason Bee Species for Biomonitoring. Sustainability 2020, 12, 9427. [CrossRef]

41. Sanyé-Mengual, E.; Specht, K.; Vávra, J.; Artmann, M.; Orsini, F.; Gianquinto, G. Ecosystem Services of Urban Agriculture: Perceptions of Project Leaders, Stakeholders and the General Public. Sustainability 2020, 12, 10446. [CrossRef]

42. Muñoz-Rodríguez, M.; Fernández-González, C.; Aguilar-Gallegos, N.; González-Santiago, M.V. The Primacy of Politics in Public Food Security Policies: The Case of Home Gardens. Sustainability 2020, 12, 4316. [CrossRef]

43. Specht, K.; Schimichowski, J.; Fox-Kämper, R. Multifunctional Urban Landscapes: The Potential Role of Urban Agriculture as an Element of Sustainable Land Management. In Sustainable Land Management in a European Context; Weith, T., Barkmann, T., Gaasch, N., Rogga, S., Strauß, C., Zscheischler, J., Eds.; Human-Environment Interactions; Springer International Publishing: Cham, Switzerland, 2021; Volume 8, pp. 291-303. ISBN 978-3-030-50840-1.

44. Sartison, K.; Artmann, M. Edible Cities-An Innovative Nature-Based Solution for Urban Sustainability Transformation? An Explorative Study of Urban Food Production in German Cities. Urban For. Urban Green. 2020, 49, 126604. [CrossRef]

45. Sanyé-Mengual, E.; Specht, K.; Krikser, T.; Vanni, C.; Pennisi, G.; Orsini, F.; Gianquinto, G.P. Social Acceptance and Perceived Ecosystem Services of Urban Agriculture in Southern Europe: The Case of Bologna, Italy. PLoS ONE 2018, 13, e0200993. [CrossRef] [PubMed] 